\title{
Analysis of Household Economic Conditions and Community Habits on The Incidence of Anemia in Pregnant Women through Household Nutrition Management in The Working Area of The Salugatta Health Center, Central Mamuju Regency
}

\author{
Nikmawati, Ansar, Rasjidin Abdullah \\ Program Pascasarjana STIE Amkop Makassar, Indonesia \\ Nikmawati@gmail.com, ansar@gmail.com,rasjidinabdullah@gmail.com \\ Jamiludin Usman \\ Institut Agama Islam Negeri Madura \\ jamiludin.usman@iainmadura.ac.id \\ Yusriadi Yusriadi \\ Sekolah Tinggi Ilmu Administrasi Puangrimaggalatung, Makassar, Indonesia \\ yusriadi.yusriadi@uqconnect.edu.au \\ Ode Yahyu Herliany Yusuf \\ Baubau Islamic Religious School (STAI) \\ yahyu85@gmail.com \\ Ida Bagus Made Wisnu Parta \\ Universitas Dwijendra \\ wisnu.goes@gmail.com
}

\begin{abstract}
Objective: This study aims to determine and analyze how much influence the economic situation and community habits have on the incidence of anemia through household nutrition management in the work area of the Salugatta Public Health Center, Central Mamuju Regency. Methods: This research was conducted in the Salugatta Health Center Work Area, Central Mamuju Regency, which was carried out for approximately 2 (two) months, from August 2020 to September 2020. The sampling technique used accidental saturation, and the final sample (Slovin's formula) was 183 people. Data collection techniques through observation, interviews, questionnaires, and documentation, while data analysis by path analysis. Results: The results showed that household economic conditions positively and significantly affected household nutrition management. The household's financial situation has improved the case in many ways, such as increasing the education of family members, income, employment, ownership of wealth, and housing. Which, in the end, can encourage the improvement of household nutrition and promote the high ability to improve the health status of families, especially pregnant women, to avoid incidents of anemia. Community habits have a positive and significant impact on household nutrition management. The pattern of community habits (pregnant women) is shown by regular physical activity. Awareness of the importance of managing pregnancy spacing, adequate rest and maintaining stamina during the pregnancy process has led to improvements in the nutritional settings they need. As well as improving good habits from the community, especially Pregnant women have shown a decrease in the incidence of anemia.
\end{abstract}

Keywords:

Economic conditions, community habits, anemia 


\section{Introduction}

Anemia is the world's most significant public health problem, especially for the reproductive age group of women (WUS). Globally the prevalence of anemia in pregnant women worldwide is $41.8 \%$. The majority of anemia in pregnant women is estimated in Asia at $48.2 \%$, Africa at 57.1\%, America at 24.1\%, and Europe $25.1 \%$ (WHO., 2016). The Government has made various efforts to address this problem, including improving the implementation of integrated antenatal services (ANC), a program to bridge meetings between pregnant women and health workers.

Anemia is associated with nutritional problems. Nutritional anemia is caused by malnutrition that plays a role in the formation of hemoglobin. It can be due to lack of consumption or absorption disorders. The cause of iron nutrient anemia is the lack of iron intake, especially in iron-hem (Hardinsyah and Supariasa, 2017).

The incidence of anemia can be caused by factors including socioeconomic factors, namely education, employment, and income, where economic improvement plays a role in fulfilling nutrition. This is supported by the results of research that has been conducted by Hammadah (2016), which explains the socioeconomic influence on the incidence of anemia. According to Manuaba (2010), anemia plays a role in the high mortality rate of pregnant women and increases with the increase in gestational age.

Anemia is one of the risk factors for maternal death. Prevention of anemia in pregnant women in Central Mamuju Regency is carried out through administering Fe Tablets to pregnant women as many as 90 tablets divided into three administrations during pregnancy. But from the observations made has not optimally suppressed anemia judging by the economic state and habits of the community. This study seeks to uncover how much influence the Economic Condition and Habits of the Community on the Incidence of Anemia Through the Management of Household Nutrition in the Working Area of The Salugatta Health Center of Central Mamuju Regency.

\section{Literature Review}

Economical circumstances will affect the level of one's ability to meet the needs of life. If the economic level is higher, the higher the quality of food with balanced nutrition will be fulfilled. On the contrary, if socioeconomic is low, it will be reluctant to meet its balanced nutrition. This is in line with the results of research / conducted by Melku, Addis, Alem, \&Enawgaw (2014) states that pregnant women with low family income are three times more at risk for anemia than mothers who have a high family income. Family income is an essential factor that affects anemia in pregnant women because it increases several other related factors such as nutrition, education, awareness and hygienic conditions (Morsy \&Alhady, 2014).

People who can implement a healthy lifestyle in daily life can succeed, especially for pregnant women, because pregnancy is the most beautiful gift given by God to every woman in the world. Maintaining a healthy lifestyle and nutritious food is one way to keep the grace of God. Healthy diet patterns with a balanced menu are essential for fetal development in the womb. But sometimes mothers-to-be pay less attention to it. But in that way, the fetus in the womb becomes healthy until the baby is born. Women, as mothers-to-be, should be encouraged to eat foods that contain a lot of nutrients. Because during pregnancy, the need for calcium, iron, and folic acid increases (Manuaba, 2010).

Nutritional management of the mother during pregnancy can affect the growth of the fetus being conceived. Mothers with malnutrition during pregnancy often give birth to babies with low birth weight (BBLR), low vitality and high mortality, especially when suffering from anemia. The impact on pregnant women can cause complications such as anemia, bleeding. BB mother does not usually increase and exposed to infectious diseases. During pregnancy, the iron needed by the body is more than when not pregnant. The process of haemodilution that occurs during pregnancy and the increasing needs of the mother and fetus, and the lack of iron intake through food resulted in decreased HB levels of pregnant women (Hanifa, 2002). One of the efforts to overcome the high prevalence of pregnant women suffering from nutritional anemia is to supplement iron tablets in pregnant women as much as one tablet every consecutive day for 90 days during pregnancy. But there is a problem faced in iron tablet supplementation: pregnant women are difficult to consume every day on the grounds of forgetting, $\mu$ eneg $\partial$ and so on. For the maximum absorption of iron, drink iron with cooked drinking water and vitamin $\mathrm{C}$ and reduce the consumption of foods that can inhibit iron absorption, such as the consumption of tea when taking iron tablets.

Economic circumstances are closely related to family income. The lack of family income leads to the reduced location and daily food purchases, thus reducing the amount and quality of mother's food per day, which impacts the decrease in nutritional status. A common dietary disorder in women is anemia because physiologically menstruate every month. The food sources needed to prevent anemia generally come from more expensive protein sources and are difficult to reach for those on low incomes. These deficiencies increase the risk of anemia in 
adolescents and pregnant women and increase the risk of pain in mothers and newborns. Anemia plays a role in the high mortality rate of pregnant women and increases with the increase in gestational age.

Getting used to living with a healthy diet indeed contains all the elements of balanced nutrition according to the body's needs, both proteins, carbohydrates, fats, vitamins, minerals and water. As much as possible, avoid foods that contain high fats, avoid preserved foods, increase the consumption of fruits and vegetables, reduce salty foods, pay attention to food processing techniques, increase the consumption of water, and avoid alcoholic beverages. This indicates that poor diet during pregnancy will cause protein and vitamin intake not to follow the needs, metabolism is not balanced so that the formation of $\mathrm{Hb}$ is hampered. The body's need for nutrients, both micro and macro, is not met. It will result in various nutritional problems and anemia, both mild, moderate and severe during pregnancy (Soetjiningsih, 2007).

Low economic (income) levels can affect diet. Most of the expenditure is aimed at meeting food needs, oriented to the type of carbohydrate food. This is because foods containing a lot of carbohydrates are cheaper than iron source foods, so the need for iron will be challenging to meet and can impact the occurrence of iron nutrient anemia (Winarni FG, 1997). The size of a family, the composition, and the income level, associated with diet's quality and quantity applied in that family. Many family members are undoubtedly different from the number of small family members in terms of food and income equality. In families with large numbers of members, the family's distribution and adequacy in the family is lacking, thus causing malnutrition and impacting anemia. According to the study results, anemia often occurs in pregnant women with an incidence rate of approximately 20-60 per cent. This incidence varies depending on the low socioeconomic conditions that result in iron deficiency anemia (Mulyono J, 2004).

Getting used to a healthy lifestyle means that people have made every effort to apply good habits to create a healthy life and avoid bad habits that can interfere with health (Wafiq Hisyam, 2007). Especially healthy food patterns consumed by pregnant women should have the number of calories and nutrients that suit their needs. Pregnant women whose diet is unhealthy can experience anemia. This can happen because of many factors that affect not taking the tablets or a type of folic acid, not consuming gestational milk, pregnant at a risky age, failure to absorb iron due to drinking tea or coffee, bleeding during pregnancy, twin fetuses. Antacids can reduce the absorption of iron released through the gastrointestinal tract to be more, and chronic diseases (Manuaba, 2010). In addition to diet, several things affect the availability of iron in foodstuffs, one of which is processing foodstuffs. The way of processing foodstuffs can affect the bioavailability of iron in foods. The method of washing, for example, can dissolve iron in the water. In addition, the process of heating foodstuffs can also affect the iron content in foods.

\section{Method}

This research was conducted in the Working Area of Puskesmas Salugatta Central Mamuju Regency, which was conducted for approximately 2 (two) months, from August 2020 to September 2020. This study uses a survey design with a quantitative approach. The population in this study is all pregnant women in the Working Area of The Salugatta Health Center of Central Mamuju Regency, including seven villages (Salugatta, Tinali, Barakkang, Salumanurung, Pontanakayang, Hada Valley and Bojo) as many as 335 people. Teknik sampling using accidentally saturated and obtained the final sample (Slovin's formula) as many as 183 people. Data collection techniques through observation, interview, questionnaire, and documentation, during data analysis with path analysis.

\section{Result}

Table 1. Test $t$ Effect of $\mathrm{X} 1$ and $\mathrm{X} 2$ on $\mathrm{Y} 1$

\begin{tabular}{|c|c|c|c|c|c|c|}
\hline & & \multicolumn{2}{|c|}{$\begin{array}{l}\text { Unstandardized } \\
\text { Coefficients }\end{array}$} & \multirow{2}{*}{$\begin{array}{c}\text { Standardized } \\
\text { Coefficients } \\
\text { Beta }\end{array}$} & \multirow[b]{2}{*}{$\mathrm{t}$} & \multirow[b]{2}{*}{ itself. } \\
\hline \multicolumn{2}{|c|}{ Model } & $\mathrm{B}$ & Std. Error & & & \\
\hline \multirow[t]{3}{*}{1} & (Constant) & 9.265 & 1.257 & & 7.373 & .000 \\
\hline & Keadaan_Ekonomi_X1 & 211 & .060 & .264 & 3.516 & .001 \\
\hline & Kebiasaan_Masyarakat_X2 & .131 & .061 & .160 & 2.130 & .035 \\
\hline
\end{tabular}

Dependent Variables: Nutrition Management (Y1)

Source: Data processing, 2020. 
The path coefficient value $(\alpha 1)=0.264$ with a significant rate of 0.001 significance $(\mathrm{Sig}<0.05)$ or the calculated $\mathrm{t}$ value $>$ table $\mathrm{t}(3,516>1,973)$. Thus, it is said that the variable Economic Condition (X1) has a positive and significant effect on Nutrition Management (Y1). The magnitude of variable X1's effect on Y1 can be seen in the standardized coefficients beta value of 0.264 points.

The path coefficient value $(\alpha 2)=0.160$ with a significant rate of 0.035 significance $(\mathrm{Sig}<0.05)$ or the calculated $\mathrm{t}$ value $>\mathrm{t}$-table $(2,130>1,973)$. Thus, it is said that Community Habits $(\mathrm{X} 2)$ variables have a positive and significant effect on Nutrition Management (Y1). The magnitude of variable X2's effect on Y1 can be seen in the standardized coefficients beta value of 2.136 points.

Table 2. Summary of Results of Coefficient of Determination Analysis

\begin{tabular}{|l|r|r|r|r|}
\hline \multicolumn{7}{|c|}{ Model Summary } \\
\hline Model & R & R Square & Adjusted R Square & Std. Error of the Estimate \\
\hline 1 & .356a & .127 & .117 & 2.136 \\
\hline a. Predictors: (Constant), Kebiasaan_Masyarakat_X2, Keadaan_Ekonomi_X1 \\
\hline
\end{tabular}

Source: Processed data, 2020

Based on table 2, The R-Square value (R2) indicates of 0.127 or $12.7 \%$. This means that $12.7 \%$ variation in the ups and downs of Nutrition Management (Y1) variables can be explained by variations in the economic state (X1) and people's habits (X2). In comparison, the remaining 100-12.7 =87.3\% are explained by other variables outside the model studied.

Table 3. Test t Effect of $\mathrm{X} 1, \mathrm{X} 2$ and $\mathrm{Y} 1$ on $\mathrm{Y} 2$

\begin{tabular}{|c|c|c|c|c|c|c|}
\hline & & \multicolumn{2}{|c|}{$\begin{array}{c}\text { Unstandardized } \\
\text { Coefficients }\end{array}$} & \multirow{2}{*}{$\begin{array}{c}\text { Standardized } \\
\text { Coefficients }\end{array}$} & \multirow[b]{2}{*}{$\mathrm{t}$} & \multirow[b]{2}{*}{ itself. } \\
\hline \multicolumn{2}{|c|}{ Model } & $\mathrm{B}$ & Std. Error & & & \\
\hline \multirow[t]{4}{*}{1} & (Constant) & 7.636 & .808 & & 9.449 & .000 \\
\hline & Keadaan_Ekonomi_X1 & .094 & .035 & .197 & 2.699 & .008 \\
\hline & Kebiasaan_Masyarakat_X2 & .089 & .035 & .182 & 2.543 & .012 \\
\hline & Pengelolaan_Gizi_Y1 & .162 & .042 & .270 & 3.851 & .000 \\
\hline
\end{tabular}

Dependent Variable: Incidence of Anemia (Y2)

Source: Data processing, 2020.

Effect of Economic Conditions (X1) on Anemia (Y2); The coefficient of path $(\beta 1)=0.197$ with a significant rate of 0.008 which means significant $(\operatorname{Sig}<0.05)$ or the calculated t value $>$ t-table $(2,699>1,973)$. Thus, it is said that the variable Economic State (X1) has a positive and significant effect on the Incidence of Anemia (Y1). The magnitude of variable X1's effect on Y2 can be seen in the standardized coefficients beta value of 0.197 points. Effect of People's Habits (X2) on Anemia (Y2); The coefficient of path $(\beta 2)=0.182$ with a significant magnitude of 0.012 means significant $(\operatorname{Sig}<0.05)$ or the calculated t value $>$ t-table $(2,543>1,973)$. Thus, it is said that the variable Habits of Society (X2) has a positive and significant effect on the Incidence of Anemia (Y2). The magnitude of variable X2's effect on Y2 can be seen in the standardized coefficients beta value of 0.197 points. Effect of Nutrition Management (Y1) on Anemia (Y2); The coefficient of path $(\beta 3)=0.270$ with a significant value of 0.000 which means significant $(\mathrm{Sig}<0.05)$ or the calculated t value $>\mathrm{t}$-table $(3,851>1,973)$. Thus, it is said that the variable Nutrition Management (Y1) has a positive and significant effect on the Incidence of Anemia (Y2). The magnitude of the influence of Variable Y1 on Y2 can be seen in the standardized coefficients beta value of 0.270 points.

Table 4. Summary of Results of Coefficient of Determination Analysis

\begin{tabular}{|l|c|c|c|r|}
\hline \multicolumn{7}{|c|}{ Model Summary } \\
\hline Model & R & R Square & Adjusted R Square & Std. Error of the Estimate \\
\hline 1 & \multicolumn{2}{|c|}{.232} & .219 & 1.204 \\
\hline a. Predictors: (Constant), Pengelolaan_Gizi_Y1, Kebiasaan_Masyarakat_X2, Keadaan_Ekonomi_X1 \\
\hline
\end{tabular}

Source: Processed data, 2020

Based on table 4, the R-Square value (R2) indicates a figure of 0.232 or $23.2 \%$. This means that $23.2 \%$ variation in the ups and downs of the Variable Incidence of Anemia (Y2) can be explained by variable variations of 
Economic State (X1), Community Habits (X2) and Nutrition Management (Y1). Meanwhile, other variables outside the model studied are explained by the remaining 100-23.2 $=76.8 \%$.

\subsection{Indirect Effect}

In calculating the amount of indirect influence, it can be calculated as follows: X1 Y1 Y2 $=(\mathrm{a} 1 \mathrm{x}$ b3 $)=(0.264 \mathrm{x}$ $0.270)=0.071 \rightarrow \rightarrow$; A value of 0.071 means that the indirect effect of variable $\mathrm{X} 1$ on variable $\mathrm{Y} 2$ through variable $\mathrm{Y} 1$ is 0.071 points; $\mathrm{X} 2 \mathrm{Y} 1 \mathrm{Y} 2=(\mathrm{a} 1 \times \mathrm{b} 3)=(0.160 \times 0.270)=0.043 \rightarrow \rightarrow$; A value of 0.043 means that the indirect effect of an $\mathrm{X} 2$ variable on a $\mathrm{Y} 2$ variable through a $\mathrm{Y} 1$ variable is 0.043 points.

\subsection{Hypothesis Test Results}

Table 5. Hypothesis test results

\begin{tabular}{|l|c|c|c|}
\hline \multicolumn{1}{|c|}{ Hypothesis } & Value & Itself & Conclusion \\
\hline $\begin{array}{l}\text { The economic situation has a positive and significant effect on the } \\
\text { management of household nutrition in the Working Area of The Salugatta } \\
\text { Health Center in Central Mamuju Regency }\end{array}$ & 0.264 & 0.001 & evident \\
\hline $\begin{array}{l}\text { Community habits have a positive and significant effect on the management } \\
\text { of household nutrition in the Working Area of The Salugatta Health Center } \\
\text { in Central Mamuju Regency }\end{array}$ & 0.160 & 0.035 & evident \\
\hline $\begin{array}{l}\text { Economic conditions positively affect the incidence of anemia in the Working } \\
\text { Area of The Salugatta Health Center of Central Mamuju Regency }\end{array}$ & 0.197 & 0.008 & evident \\
\hline $\begin{array}{l}\text { Community habits positively affect the incidence of anemia in the Working } \\
\text { Area of The Saluggata Health Center in Central Mamuju Regency }\end{array}$ & 0.182 & 0.012 & evident \\
\hline $\begin{array}{l}\text { Household nutrition management positively affects the incidence of anemia } \\
\text { in the Working Area of Salugatta Health Center in Central Mamuju Regency }\end{array}$ & 0.270 & 0.000 & evident \\
\hline $\begin{array}{l}\text { Economic conditions positively affect the incidence of anemia through the } \\
\text { management of household nutrition in the Working Area of The Salugatta } \\
\text { Health Center of Central Mamuju Regency }\end{array}$ & 0.268 & 0.000 & evident \\
\hline $\begin{array}{l}\text { Community habits positively affect the incidence of anemia through the } \\
\text { management of household nutrition in the Working Area of The Salugatta } \\
\text { Health Center of Central Mamuju Regency }\end{array}$ & 0.225 & 0.000 & evident \\
\hline
\end{tabular}

\section{Discussion}

The influence of economic conditions on household nutrition management is in the working area of Salugatta Health Center, Central Mamuju Regency. Positive and significant, the study's findings are supported by research (Burhani et al., 2016; Nilakesuma et al., 2015; Roficha et al., 2018; Sebataraja et al., 2014; Wandani, 2021). The excellent economic condition of the family can meet all needs, including the fulfilment of nutrition, so it is undeniable that a sound economic level can be demonstrated by improving education and, of course, better understanding a healthy lifestyle and how to meet it.

Influence of Community Habits on Household Nutrition Management in The Working Area of Salugatta Health Center, Central Mamuju Regency. Positive and significant, the study's findings are supported by research (Fitriana et al., 2021; Gaspersz et al., 2020; Masrikhiyah, 2020; Wati \&Priastana, 2020). People's habits become commonplace every day and can impact their health, especially for pregnant women with good habits such as physical activity, setting pregnancy distance, sleep patterns and maintaining health implications on the better level of nutrition management carried out.

The Effect of Economic Conditions on The Incidence of Anemia in the Working Area of Salugatta Health Center, Central Mamuju Regency. Positive and significant, the findings of this study are supported by research (Hartati \&Wahyuni, 2018; Mariza, 2016; Purwaningtyas \&Prameswari, 2017; Septiasari, 2019). The community's economic condition is a condition that allows them to meet daily needs and has an impact on their level of wellbeing and health. An excellent financial condition will improve a person's condition physically and psychologically, avoid pressure and stress, and meet all his needs such as nutrition and others. It can prevent anemia, which is a risk factor for pregnant women who lack adequate nutritional intake. Good economic conditions will be able to lower the incidence of anemia.

Influence of Community Habits on The Incidence of Anemia in the Working Area of Salugatta Health Center, Central Mamuju Regency. Positive and significant, supported by research (Mariana et al., 2018; Purwaningtyas \&Prameswari, 2017; Rimawati et al., 2018; Septiawan \&Sugerta, 2016). People's habits are routines and lifestyles 
that are commonly done daily, and most of these habits can impact public health. Pregnant women can avoid anemia as an expected occurrence because of the negative impacts that can be caused. Creating good habits in the family can prevent the occurrence of anemia and its risks. Thus, good habits of society in his life will decrease the incidence of anemia.

The Effect of Nutrition Management on The Incidence of Anemia in the Working Area of Salugatta Health Center, Central Mamuju Regency. Positive and significant, supported by research (Anggraini et al., 2018; Najdah \&Yudianti, 2020; Parulian, 2018; Purwati, 2020; Simbolon, 2018). Nutrition management is a form of nutritional management shown by the fulfilment of good nutrition to compensate for the condition when pregnancy occurs. The need for adequate nutrient intake becomes an important consideration when pregnancy occurs. The goal is to avoid adverse effects such as anemia so that good nutrition management can encourage a decrease in the incidence of anemia.

The Effect of Economic Conditions on The Incidence of Anemia Through Nutrition Management in the Working Area of Salugatta Health Center, Central Mamuju Regency. Positive and significant, economic condition is a condition where the fulfilment of needs becomes more accessible, especially in health conditions. Good economic conditions will encourage the completion of suitable nutritional needs to avoid various risk factors of disease.

Influence of Community Habits on Anemia Events Through Nutrition Management in the Working Area of Salugatta Health Center, Central Mamuju Regency. Positive and significant, people's habits are daily routines carried out continuously to give the impression of mandatory to do. Still, good public habits in maintaining health, especially for pregnant women, will influence habits in regulating nutrition intake to meet health standards. It will undoubtedly be able to minimize various diseases and other adverse effects such as anemia events.

\section{Conclusion}

Based on the results and discussions, it can be concluded that the household economy has a positive and significant effect on the management of household nutrition. The economic situation of households in the Salugatta Health Center Working Area of Central Mamuju Regency has improved in many ways. Such as improved education of family members, income, employment, ownership of wealth and housing that ultimately can encourage the improvement of household nutrition. The state of the household economy positively affects the incidence of anemia. The progress of the household economy in the Working Area of The Salugatta Health Center of Central Mamuju Regency encourages the high ability to improve families' health especially pregnant women, to avoid the incidence of anemia. People's habits have a positive and significant effect on the management of household nutrition. The habitual pattern of the community (pregnant women) in the Working Area of The Salugatta Health Center of Central Mamuju Regency is shown by regular physical activity, awareness of the importance of regulating the distance of pregnancy, adequate rest and maintaining stamina during the pregnancy process. It has led to improvements in the nutritional arrangements they need. Community habits have a positive effect on anemia. The progress of good habits of the community, especially pregnant women, has shown a decrease in anemia in the Working Area of The Salugatta Health Center in Central Mamuju Regency.

\section{References}

Anggraini, D. D., Purnomo, W., \& Trijanto, B. (2018). Interaksi Ibu Hamil dengan Tenaga Kesehatan dan Pengaruhnya terhadap Kepatuhan Ibu Hamil Mengonsumsi Tablet Besi ( $\mathrm{Fe}$ ) dan Anemia di Puskesmas Kota Wilayah Selatan Kota Kediri. Buletin Penelitian Sistem Kesehatan, 21(2), 89-92.

Burhani, P. A., Oenzil, F., \& Revilla, G. (2016). Hubungan tingkat pengetahuan ibu dan tingkat ekonomi keluarga nelayan dengan status gizi balita di Kelurahan air Tawar Barat Kota Padang. Jurnal Kesehatan Andalas, 5(3).

Fitriana, T. A., Mardiyati, N. L., \& Gz, S. (2021). Hubungan Kebiasaan Sarapan Dengan Status Gizi Pada Anak Usia 5-18 Tahun: A Narative Review. Universitas Muhammadiyah Surakarta.

Gaspersz, E., Picauly, I., \& Sinaga, M. (2020). Hubungan Faktor Pola Konsumsi, Riwayat Penyakit Infeksi, Dan Personal Hygiene Dengan Status Gizi Ibu Hamil Di Wilayah Lokus Stunting Kabupaten Timur Tengah Utara. Jurnal Pangan Gizi Dan Kesehatan, 9(2), 1081-1090.

Hanifa, Winkjosastro. (2002). Ilmu Kebidanan. Jakarta: Penerbit PT.EGC

Hardinsyah dan Supariasa, IDN. (2017). Ilmu Gizi Teori dan Aplikasi. Penerbit Buku Kedokteran EGC. Jakarta

Hartati, L., \& Wahyuni, S. (2018). Hubungan Sosial Ekonomi Dengan Kejadian Anemia Pada Ibu Hamil TM III Di Puskesmas Jatinom. MOTORIK Jurnal Ilmu Kesehatan, 13(27).

Manuaba, IBG. (2010). Ilmu Kesehatan, Penyakit Kandungan Dan Keluarga Berencana. Jakarta : EGC.

Mariana, D., Wulandari, D., \& Padila, P. (2018). Hubungan Pola Makan dengan Kejadian Anemia pada Ibu Hamil di Wilayah Kerja Puskesmas. Jurnal Keperawatan Silampari, 1(2), 108-122.

Mariza, A. (2016). Hubungan pendidikan dan sosial ekonomi dengan kejadian anemia pada ibu hamil di BPS T Yohan Way Halim Bandar Lampung tahun 2015. Holistik Jurnal Kesehatan, 10(1), 5-8.

Masrikhiyah, R. (2020). Pengaruh Kebiasaan Sarapan Dan Status Gizi Remaja Terhadap Prestasi Belajar. Jurnal 
Ilmiah Gizi Dan Kesehatan (JIGK), 2(01), 23-27.

Melku, M., Addis, Z., Alem, M., \& Enawgaw, B.,(2014). Prevalence and predictors of maternal anemia during pregnancy in Gondar, Northwest Ethiopia: An institutional based cross-sectional study. HindawiPublishing Corporation, 2014, 1-9.

Mulyono Joyomartono. (2004). Pengantar Antropologi Kesehatan. Semarang: UNNES Press

Najdah, N., \& Yudianti, Y. (2020). Status Gizi dan Anemia pada Ibu Hamil dengan Berat Badan Lahir. Jurnal Ilmiah Permas: Jurnal Ilmiah STIKES Kendal, 10(1), 57-62.

Nilakesuma, A., Jurnalis, Y. D., \& Rusjdi, S. R. (2015). Hubungan status gizi bayi dengan pemberian ASI ekslusif, tingkat pendidikan ibu dan status ekonomi keluarga di Wilayah Kerja Puskesmas Padang Pasir. Jurnal Kesehatan Andalas, 4(1).

Parulian, I. (2018). Strategi dalam penanggulangan pencegahan anemia pada kehamilan. Jurnal Ilmiah Widya, $4(3)$.

Purwaningtyas, M. L., \& Prameswari, G. N. (2017). Faktor kejadian anemia pada ibu hamil. HIGEIA (Journal of Public Health Research and Development), 1(3), 43-54.

Purwaningtyas, M. L., \& Prameswari, G. N. (2017). Faktor kejadian anemia pada ibu hamil. HIGEIA (Journal of Public Health Research and Development), 1(3), 43-54.

Purwati, P. (2020). Gizi Seimbang untuk Pencegahan Anemia. Jurnal ABDIMAS-HIP: Pengabdian Kepada Masyarakat, 1(2), 69-72.

Rimawati, E., Kusumawati, E., Gamelia, E., \& Nugraheni, S. A. (2018). Intervensi Suplemen Makanan Untuk Meningkatkan Kadar Hemoglobin Pada Ibu Hamil. Jurnal Ilmu Kesehatan Masyarakat, 9(3), 161-170.

Roficha, H. N., Suaib, F., \& Hendrayati, H. (2018). Pengaruh Pengetahuan Gizi Ibu Dan Sosial Ekonomi Keluarga Terhadap Status Gizi Balita Umur 6-24 Bulan Di Wilayah Kerja Puskesmas Tamalanrea Jaya. Media Gizi Pangan, 25(1), 39-46.

Sebataraja, L. R., Oenzil, F., \& Asterina, A. (2014). Hubungan Status Gizi dengan Status Sosial Ekonomi Keluarga Murid Sekolah Dasar di Daerah Pusat dan Pinggiran Kota Padang Lisbet Rimelfhi Sebataraja. Jurnal Kesehatan Andalas, 3(2).

Septiasari, Y. (2019). Status Ekonomi Berperan Dalam Kejadian Anemia Pada Ibu Hamil Di Puskesmas Bernung Pesawaran. Jurnal Ilmiah Kesehatan, 8(1), 14-19.

Septiawan, Y., \& Sugerta, E. (2016). Hubungan Kebiasaan Minum Teh dengan Kejadian Anemia pada Ibu Hamil Trimester II di Puskesmas Kotabumi II Kabupaten Lampung Utara. Jurnal Kesehatan, 6(2).

Simbolon, D. (2018). Modul Edukasi Gizi Pencegahan dan Penanggulangan Kurang Energi Kronik (Kek) dan Anemia Pada Ibu Hamil. Deepublish.

Soetjiningsih. (2007). Tumbuh Kembang Anak. Surabaya: Penerbit Buku Kedokteran.

Wandani, Z. S. A. (2021). Pengaruh Status Pendidikan, Ekonomi, dan Pola Asuh Orang Tua terhadap Status Gizi Anak Balita di Kecamatan Pujon Kabupaten Malang.

Wati, N. P. R. L., \& Priastana, I. K. A. (2020). Hubungan Perilaku Sosial dengan Kebiasaan Makan pada Anak Status Gizi Kurang. Jurnal Kesehatan Terpadu (Integrated Health Journal), 11(2), 79-83.

WHO. (2016). World Health Organization. Anemia.ibu hamil.

Winarno FG. (1997). Kimia Pangan dan Gizi. Jakarta: Gramedia Pustaka Utama

\section{Biographies}

Nikmawati is a student at Magister Program of Economic Science of STIE AMKOP, Indonesia. Her areas of interest and research include social science and economic. She has published some articles in national journals.

Ansar is a lecturer at Economics Department of STIE AMKOP, Indonesia. His areas of interest and research include economic, management, management human resource. He has published some books and many articles in national and international journals.

Rasjidin Abdullah is a lecturer at Economics Department of STIE AMKOP, Indonesia. His areas of interest and research include economic, management, management human resource. He has published some books and many articles in national and international journals.

Jamiludin Usman is a lecturer at the Tarbiyah Faculty of IAIN Madura in Pamekasan Madura, East Java, Indonesia. His research fields and interests include management science, education, and Islamic studies. As a lecturer, he has published several scientific articles in both national and international journals. Apart from that, he has also published several books. He is also the Sinta 2 accredited scientific journal (Tadris: Islamic Education Journal) issued by the Tarbiyah Faculty of the Madura State Islamic Institute. 
Yusriadi Yusriadi is a lecturer at Public Administration Department of Sekolah Tinggi Ilmu Administrasi Puangrimaggalatung, Indonesia and chancellor on Sekolah Tinggi Ilmu Hukum Pengayoman. His areas of interest and research include social science, political science, sociology, legal studies, and public administration. He has published some books and many articles in national and international journals. He is a reviewer and editor in some local and international journals.

Ode Yahyu Herliany Yusuf, He is a lecturer at the YPIQ Baubau Islamic Religious School (STAI). Strata One He took the Muhammadiyah University of Semarang (UNIMUS), the Nursing and Masters Study Program at Yogyakarta State University (UNY). Currently he is actively publishing his papers in national journals

Ida Bagus Made Wisnu Parta is a lecturer at Dwijendra University. currently still active in the process of teaching and researching 